\title{
Vulnerability and Poverty During Covid-19: Religious Minorities in India
}

The Covid-19 pandemic has had direct and indirect effects on religiously marginalised groups, exacerbating existing inequities and undermining the ambitions of Sustainable Development Goals (SDGs) to reach (and include) those 'furthest behind'. Religious inequalities intersect with other inequalities to compound vulnerabilities, particularly the convergence of low socioeconomic status, gender inequality, and location-specific discrimination and insecurity, to shape how people are experiencing the pandemic. This policy briefing, written by Dr Joanna Howard (IDS) and a co-author (who must remain anonymous for reasons of personal security), draws on research with religious minorities living in urban slums in Tamil Nadu and Karnataka states in India. Findings show that religiously motivated discrimination reduced their access to employment and statutory services during the pandemic. Harassment and violence experienced by Muslims worsened; and loss of livelihoods, distress, and despair were also acutely experienced by dalit Hindus. Government response and protection towards lower caste and religious minorities has been insufficient.

\section{Key messages}

- The Covid-19 pandemic has devastated the livelihoods of those most vulnerable to crisis in the urban slums of India, including people who work in construction and trades, street and market traders, and domestic workers.

- Religious identity has amplified the economic shock of the pandemic. National legislation (the Citizenship Amendment Act) had already systematically marginalised Muslims, feeding a negative media narrative that led to their subsequent persecution during the pandemic. They are less likely to retain their jobs and regularly experience verbal abuse and physical harassment when they leave their homes, having been scapegoated in the media, on social media, and by public figures as spreaders of Covid-19.

- The pandemic has had a significant impact on mental health. Distress and despair due to hunger and loss of livelihoods during lockdown was acute amongst dalit Hindus, but also amongst Muslims who, already scapegoated are now exhausted by targeting, harassment, and constant fear.

- Lack of or insufficient state protection for religious minorities being targeted has led to increasing levels of violence, particularly towards Muslim men. Muslim research participants were reluctant to report discrimination for fear of reprisals but eventually shared that they had experienced harassment and beatings.

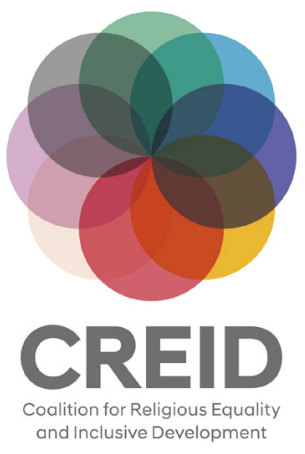


India context - religious minorities, insecurity, and Covid-19

India is a religiously diverse country. As of 2020, Hindus make up 78.9 per cent of the population while Muslims comprise the second-largest religious group and 15.4 per cent of India's population (approximately 213 million people, the second largest Muslim population in the world, after Indonesia). Christians are the next largest grouping, at 2.4 per cent, with Christian populations found across the country, but with greater concentrations in the northeast and in the southern states of Kerala, Tamil Nadu, and Goa. Other religious minorities include Sikhs, Buddhists, and Jains, which have millions of followers in India but constitute a very small percentage of the total population. ${ }^{1}$

While the Indian constitution is often understood to be secular, not all secularisms are alike. The Indian government has adopted what has been called a 'principled distance' vis-à-vis religion: it has not shied away from what may be simply called an 'internal regulation' of the legitimacy of religious practices and beliefs of different religious traditions, including the majority religious tradition, Hinduism. The Indian constitution is notable because it recognises the centrality and value of religion and therefore is not 'secular' in the traditional sense.

\section{Conversion, Scheduled Castes, and Scheduled Tribes}

More than 250 million people, or 24 per cent of India's population, belong to Scheduled Castes (SC, also known as dalits) and Scheduled Tribes. Historically, members of SC communities have been converts from Hinduism to other religions, especially Christianity and Islam, possibly motivated in part to escape caste discrimination. Many continue to face discrimination and other impediments to social advancement. Nationalist Hindu groups regularly express concern about SC conversion from Hinduism and try to stem the tide by supporting legal and social impediments to conversion. Those who convert encounter legal restrictions affecting their access to affirmative action-style benefits. They may also face social repercussions, such as attempts to forcibly convert them back to Hinduism, exclusion from water sources and public distribution systems, and violence. ${ }^{2}$ The 2019 amendment to the Citizenship Act, 1955 (Citizenship Amendment Act (CAA)), introduced by the Bharatiya Janata Party (BJP), provides a pathway to citizenship for persecuted religious minorities but excludes Muslims, which led to widespread protests in 2019/20.

At state level, the different configurations of political parties and religious minorities are producing varying experiences of insecurity, which makes it difficult to generalise about restrictions on minorities in India. In Kerala, for example, there are few restrictions on religious minorities; in fact, the main restrictions apply to its majority Hindus. In Tamil Nadu, however, there has been a rise in anti-Christian intimidation, harassment, and violence across the state, with 322 anti-Christian incidents between 2011 and mid-2020. ${ }^{3}$ Muslim-led protests in Tamil Nadu in early 2020 (in response to the CAA) led to arrests by police of a large group from Al Jamaat (a Muslim missionary organisation) and 15 other Muslim organisations in Coimbatore city. Some of the Muslims living in Chennai that we spoke to claimed to have
At state level, the different configurations of political parties and religious minorities are producing varying experiences of insecurity, which makes it difficult to generalise about restrictions on minorities in India 
been wrongfully arrested on charges of assaulting Hindus under the Unlawful Activities Prevention Act. In the state of Karnataka, consistent with the state-region pattern of religious violence and religious restriction in BJP-controlled states, right-wing Hindu nationalist activists have prompted communal clashes and religion-related violent attacks. On 11 August 2020, violent clashes took place in a Muslimmajority slum in Bangalore, triggered by an inflammatory Facebook post about the prophet Mohammed, said to be posted by the nephew of a state legislator of the Indian National Congress.

The pandemic has exacerbated religious discrimination, and Muslim minorities, in particular, have been scapegoated for the spread of the virus. Religious minorities including Muslims, Christians,

\section{Methodology note}

The selected sites were slums in north Chennai and north Bangalore, both capital cities of their respective states, to facilitate a deeper understanding of the multi-factor dynamics of urban poverty and wellbeing in the context of the current Covid-19 pandemic. In Chennai, the majority of slum residents are dalits, particularly dalit Muslims who have lived there for decades. They are mostly daily wage labourers who formerly

\section{Research process}

Twelve participatory inquiry groups were conducted with a total of 96 participants, collecting data through drawings, individuals' reflections, ranking and scoring matrices, and 16 semi-structured interviews. Separate groups of men and women from each religious minority were convened,

\section{Research tools}

Inquiry groups in each site began with a River or Road of Life exercise, which enabled participants to each share the stories of their lives over the last 18 months, from before the pandemic to their experiences of life in the shadow of Covid-19. This exercise prompted group discussion of the issues and was followed

\section{Challenges to the research}

Pandemic restrictions and fear (especially following the CAA) posed constraints on the research process. However, the combination of participatory group methods and personal interviews helped to build trust between facilitators worked in the harbour, at the railway station, and as domestic labourers and lost their jobs during the pandemic. North Bangalore has one of the largest concentrations of lowincome Muslims and Christians in Karnataka state and is managed by the Indian National Congress Party (the opposition party) municipal council members - relevant for an understanding of political party impact on religious minority experiences.

with facilitators of the same religion and gender where possible. The experiences of comparator groups were also considered, i.e. with SC men and women living in poverty. Discussions were conducted in participants' preferred language (Urdu, Tamil, Kannada, Hindi, English).

by a PRA matrix ranking exercise to identify the group's most pressing issues. During discussions, major themes emerged, prompted with additional questions from the researchers. Semi-structured interviews were conducted with selected participants to deepen or complement the inquiry group data.

and participants. Researchers also worked closely with non-governmental organisation (NGO) staff from Hindu, Muslim, and Christian backgrounds to lay the foundation for the inquiry groups, which took place over January and February 2021. 
and dalit Hindus living in poverty have faced increased barriers to accessing livelihoods: they are more likely to be laid off, less likely to access government support during the pandemic, and more likely to be forced to work without suitable protective equipment, or face deeper debt and hardship.

\section{Key findlings}

- The impact of Covid-19 on Muslims and Christians living in poverty in India has manifested in terms of livelihoods, income and debt, access to assistance, health, security, and education. The research also noted the negative impacts on the comparator dalit Hindu groups.

- Loss of livelihoods during lockdown has left many unable to pay interest on loans or to pay rent and school fees, leading to high levels of anxiety and reports of harassment. Hunger was highlighted more by dalit Hindus, due to insufficient government rations and temple closures, whereas churches and mosques provided food aid to their congregations. Government assistance was not received by most religious minority participants, and Christians reported deliberate exclusion from assistance based on their names.

- Social ostracisation has increased in response to fear of Covid-19 combined with underlying prejudice towards religious minorities. This isolation, combined with hunger and debt, is triggering mental health crises amongst religious minorities and the poorest dalit Hindus.

- Muslims are significantly at greater risk of insecurity and religiously motivated harassment than other religious minorities, and they were fearful to speak to the researchers. Most Muslim participants spoke of their fear of physical attack. They experienced intimidation before Covid-19, and the pandemic has brought an increase due to scapegoating and targeting, with more violent attacks experienced in Bangalore than in Chennai, indicating the impact of a BJPcontrolled state government.

\section{Economic impacts, especially for women}

All the research participants are from slums and work in the informal sector without financial safety nets or capital to fall back on. For all these communities, there is a huge additional challenge for women - and especially single mothers/female-headed households - to find work while facing discrimination and stigma outside the home and managing caring duties at home. The intersection of poverty and gender heightened the vulnerability of religious minority women during the pandemic. Dalit Hindu women in Chennai highlighted that government assistance is for widows but not for wives whose husbands have left them, and that social norms prescribe what jobs they can do, or even prevent them from work.

More broadly, most respondents were unable to pay their rent, or had to take out new loans, and were threatened and harassed by the lenders. There is a critical intersection of vulnerability through faith
Social

ostracisation in response to fear of Covid-19, underlying prejudice, hunger, and debt are triggering mental health crises amongst religious minorities and the poorest dalit Hindus 
(or caste) identity, and extreme poverty, which created higher levels of insecurity during the pandemic for these groups relative to people of middle class and majority religion. As Hindu men in Chennai identified, it is structural injustice and the subsequent encroachment on rights which leaves people with few options but to break lockdown rules to go to work and get beaten, or to steal or beg:

So corona is a fact that we all are affected and trapped but beyond that we are trapped in many other spider webs like these. So we cannot do anything. They say we should maintain social distancing, but this rule is not for [them]... Because people like us are busy running after income to survive.

In both Chennai and Bangalore, religious minorities received most of their assistance either in the form of cash handouts or food rations through religious institutions and communities. In some cases in Chennai, religious minorities were given food rations by government authorities. However, few minority respondents reported receiving donations from the government in Bangalore. Hindus reported there being no help from temples due to the strict regulations on Hindu institutions during lockdown, but that there was more consistent access to government rations and help from NGOs.

\section{Broader health impacts of Covid-19 and public measures to contain it}

Participants across all faith groups spoke of how Covid-19 has impacted on their health for several reasons. Stress has undoubtedly contributed to poor health, especially in relation to high blood pressure and diabetes, which were widely mentioned. Some were unable to go to hospital because there were cases of Covid-19 there. Health issues, mainly unrelated to Covid-19, have had to be addressed and treatment and medication paid for when people have had no income. As a result, when health issues are serious, people have become very indebted. Members of minority groups were shunned and verbally abused when they caught the virus, including this Christian woman from Chennai:

My area is slum, so houses [are] closer. They used to talk nicely, but when the people from [the local municipal] corporation confirmed that my husband has corona, they blasphemed me. Because it reached my house first, they treated us as untouchable and as if we had spread it everywhere.

Such labelling and ostracisation may result in members of religious minorities not disclosing that they have or suspect that they have Covid-19, causing a risk to public health.

Another area of concern is the number of people who reported experiencing mental health issues, including depression, despair, fear, sleeplessness, and suicidal thoughts. This was noticeable amongst all groups, but particularly prevalent in the Hindu groups who reported loneliness, isolation, and the fear of not being able to pay back loans. The economic impact of the pandemic appears to be most acute for dalit Hindus who in many cases have not had access to resources from religious institutions to help them.
The intersection

of vulnerability

through faith

(or caste) identity, and extreme

poverty created

higher levels of insecurity during the pandemic compared to people of middle class and majority religion 
Increase of violence towards religious minorities as a result of Covid-19

During the inquiry groups, Muslim men in Bangalore initially kept silent about their experiences of religious discrimination and harassment, but once reassured that they could talk openly, they listed many examples of violence, beatings, imprisonment, and scapegoating. This was happening before the pandemic, but continued more freely under the justification of Covid-19 lockdown restrictions.

We Muslims really suffered because we were Muslim. They caught us Muslim men and harassed us. Everywhere they grabbed us and hit us. Hindu men grabbed us in different places and hit us.

Although Muslims have been worst affected by communal violence, the policing of lockdown in India has created security issues for many of our religious minority respondents who, facing hunger and desperation at home, have had to leave their houses to seek work or borrow money. They were regularly confronted by police, harassed, and sometimes beaten.

\section{Gendered impacts}

Hindu and Christian women spoke of their husbands' drinking and abuse, although conversely, Christian women in Chennai shared how one unexpected silver lining of the lockdown was that their husbands stopped drinking, and some were more helpful at home. Many women continued to do all the work in the home. Muslim and Christian women are also more vulnerable because they are regarded by the wider Hindu population as 'unclean/polluted', not only because they come from a lower caste, but also because they work in polluting jobs such as cleaning toilets, sweeping floors, or dealing with sewage and sanitation. Those who worked as domestic servants were often dismissed during the pandemic because of these damaging norms, which were exacerbated by the emphasis on the need to be extra 'clean' and 'sanitary' to avoid catching Covid-19.

\section{Impact on schooling and education}

A troubling impact of the pandemic on religious minority children living in poverty is that they have lost over a year of schooling due to their homes lacking the resources to engage in lessons. Numerous families are having to share one phone between all the children; in other cases, they have given up and the children are not studying at all. Parents struggle to help their children with their studies, as many do not speak English. The longer-term consequences of this loss of schooling may compound poverty across generations, which in turn will reinforce and deepen marginalisation and stigmatisation of religious minorities. Many participants, despite living in poverty, prioritise private schooling for their children since private schools generally teach in English and have better educational outcomes than government schools. In addition, children who attend private schools have a better chance of attending further education because most private and good state universities only accept students who complete high school in English.
The policing of

lockdown created

security issues

for many of our

religious minority

respondents who, facing hunger

and desperation,

had to leave their

houses to seek

work or borrow

money 


\section{Policy recommendations and proposed actions}

1 Repeal laws that foster religious discrimination and religiously motivated violence against vulnerable religious minorities that exacerbate and intensify long-standing persecution and prejudice.

- India has laws, both proposed and in use, that threaten the secular and non-discriminatory foundations of the Indian state. These include the proposed National Register of Citizens (NRC). In Assam, the draft legislation has led to the declaration of four million people as non-citizens due to the lack of evidence of citizenship, a move that disproportionately affects the large number of Muslims who have migrated from neighbouring Bangladesh.

- Similarly, the Citizenship Amendment Act (CAA), a bill to amend India's citizenship laws to provide a pathway to citizenship for undocumented immigrants from Afghanistan, Bangladesh, and Pakistan, but expressly excluding those who are Muslims, is now law. The CAA, in conjunction with a call to create a National Population Register (NPR) as well as the NRC, has led to widespread fears that many Indian citizens will be left out due to poor documentation or may be targeted due to their religious faith.

- At a time when the general population is highly fearful of infection and unemployment, it is imperative that specific religious groups are not made to appear responsible, put at risk of ostracisation, or face more violent forms of targeting where they live.

2 To ensure religious minorities are included in pandemic and post-pandemic relief efforts, international donors, including the Foreign, Commonwealth \& Development Office (FCDO), the World Bank and other agencies, should consider both relaxing restrictions on grants to faith-based organisations, particularly minority-run ones, and introducing conditionalities in their loans.

- Since Prime Minister Modi took office in 2014, more than 11,000 NGOs have lost their licences to accept foreign funds as a result of the Foreign Contribution Regulation Act, which regulates foreign contributions to NGOs. Local faith-based organisations and faith communities often already exist or operate in crisis-affected regions, so they are well placed to address urgent development needs as a result of their deep awareness of the particular contextual needs both material and spiritual - of religious minorities. The operation of such grass-roots faith-based organisations could be enhanced if there is an effort amongst donors to reduce the heavy bureaucratic hurdles that often prevent them from accessing funding. Additionally, donors can include conditionalities in their loans to ensure that faith-friendly government agencies and minority institutions are able to disburse funds and/or faith-based organisations, particularly minority-run ones, are allowed to receive funds.

- It is important to note that dalit Hindus have been severely affected by the pandemic, with an insufficient government response to protect them. The specific vulnerabilities of dalits and religious minorities must be considered in pandemic responses, with
The longer-term consequences of the loss of schooling for religious minority children living in poverty may compound poverty across generations 
particular attention to the protection of women. We recommend that large international aid agencies work closely with religious communities, particularly local religious communities, to identify and address the more specific needs of the vulnerable religious minorities in their context.

- Employing a twin-track approach of both mainstreaming and targeting interventions for religious minorities should be considered during project planning and development. For example, an effective oxygen supplies programme will have taken into consideration how religious minorities would access its services so they are not further excluded (mainstreaming); or a targeted intervention such as a vaccine service programme might focus on building the capacity of religious minority institutions to provide services to their co-religionists without being deliberately prevented from accessing certain - and life-giving - goods and services.

3 Strengthen and support the role of religious communities and institutions to provide spiritual and mental help to individuals from both minority and majority religious communities.

- This study found that the pandemic has had a deleterious effect on the economic, social, and spiritual lives of the poor. Individuals from all religious communities talked openly about depression and isolation. Local religious actors and institutions have a long history and are uniquely positioned to meet the social, material, and spiritual needs of their co-religionists. These religious communities are well networked, internally funded, locally accountable, and invested in the long-term development of their communities.

\section{Deliberate and conscious consideration should be given to} protecting women during the pandemic.

- International and national aid agencies and other key donors need to encourage and provide opportunities for women to voice their concerns about abandonment, domestic violence, rape, and sexual abuse, which has increased since the start of the pandemic.

- International and humanitarian aid agencies should be strongly persuaded to work closely with grass-roots agencies and civil society organisations that are deeply embedded in the local communities and with whom women have built a solid foundation of trust.

5 Demonstrate cultural and religious sensitivity while working with religious communities.

- Assisting religious minorities in crises also requires cultural sensitivity with respect to dealing with sensitive topics such as religiously motivated violence, persecution, and cultural tensions, which have been exacerbated during the pandemic.

- Choosing an aid worker or supporting a religious minority institution to serve needy communities shows respect for the faith, which can in turn create a bridge between aid agencies and religious groups, but care must be taken to operate in a way that is sincere and respectful.
The specific vulnerabilities of

dalits and religious minorities must be considered in pandemic responses, with particular attention to the protection of women 
6 Develop vulnerability criteria for assistance that includes religious vulnerability.

- Every effort should be taken to address degrees of vulnerability of religious minorities during the pandemic. While all religious minorities, including Jains, Sikhs, and Buddhists, may be at high risk due to the significant economic, health, and social impacts of the pandemic, some minorities, such as dalit and low-income Muslims and Christians, are at acute risk of religiously motivated violence, exclusion, and in some cases, systematic targeting or indiscriminate violence and harassment based on religion and caste.

- A vulnerability assessment must be conducted to ascertain degrees of vulnerability and the intensity of the hostility to which particular groups may be subject (ranging from beatings to mass murder). For example, in some contexts, members of religious minorities who are women, converts from the favoured religion, or those accused of blasphemy or apostasy, may be relatively unprotected and subject to particularly intense violence, such as rape or even death. A triage of responses should then be developed and deployed accordingly. Such information must be shared with international humanitarian agencies and with key donor agency personnel in-country.

\section{Strengthening the evidence base on religious minorities during the pandemic.}

- Careful and sensitive data on the more specific needs of religious minorities should be collected throughout and after the pandemic to measure the impact of indirect effects on these vulnerable communities.

- Good data are essential for the FCDO, for example, to provide targeted programming for religious minorities and to fund such programmes through UK-based organisations in India. However, given the risk inherent in collecting highly sensitive information on religion and ethnicity, careful attention is needed on how the data are collected and with whom it is shared to avoid further endangering vulnerable religious communities. For example, aid agencies may deliver more targeted social protection and aid to these groups by collecting detailed religiously disaggregated data at a community level, but at the same time, they need to ensure they are able to protect the confidentiality and security of individuals.

\section{Notes}

1 Country population data are derived from United Nations Population Division (2019). Religious affiliation proportions are derived from Pew Research Center (2020).

2 Conversation between J. Barker and L. Adams and Father Ajaya Singh, 13 February 2018.

3 See Evangelical Fellowship of India (EFI) website for detailed data. 


\section{Further reading}

Arockiasamy, C. (2020) Covid-19 Adds Yet Another Strain to the Dire Situation of Religious Minorities in India, CREID blog, 21 May (accessed 14 October 2021)

Barry, E. and Raj, S. (2017) 'Major Christian Charity is Closing India Operations Amid a Crackdown', New York Times, 7 March (accessed 29 April 2021)

Bharadwaj, S.; Howard, J. and Narayanan, P. (2020) Using Participatory Action Research Methodologies for Engaging and Researching with Religious Minorities in Contexts of Intersecting Inequalities, CREID Working Paper 5, Brighton: Institute of Development Studies

Bhargava, R. (1998) 'Introduction', in R. Bhargava (ed.), Secularism and its Critics, New Delhi: Oxford University Press: 1-30

Dutta, P.K. (2019) ‘CAA, NPR and NRC: Confusion and Connection Explained', India Today, 26 December (accessed 29 April 2021)

Hankivsky, O. and Kapilashrami, A. (2020) 'Intersectionality Offers a Radical Rethinking of Covid-19', BMJ 20.09: 26

Karmakar, R. (2018) 'Over 40 Lakh Left Out of Draft NRC in Assam', The Hindu, 31 July (accessed 29 April 2021)

Nazeer, A. (2020) India's Muslim Minority Experiences Increased Targeting and Violence During Covid-19, CREID blog, 4 June (accessed 14 October 2021)

Office of the Registrar General and Census Commissioner (2021) Census of 2001: Scheduled Castes and Scheduled Tribes, Ministry of Home Affairs, Government of India (accessed 5 June 2020)

Pew Research Center (2020) 'India Country Profile', Pew-Templeton Global Religious Futures Project (accessed 5 June 2020)

Ryan, N. and Al-Ayadi, A. (2020) 'A Call for a Gender-Responsive, Intersectional Approach to Address Covid-19', Global Public Health 15.9: $1404-12$

Shah, R.S. (2021) 'The Freedom of Religious Institutions and Human Flourishing in India: A Present and Future Research Agenda', Religions 12.7: 550 (accessed 14 October 2021)

United Nations Population Division (2019) 'Total Population - Both Sexes', World Population Prospects: The 2019 Revision (accessed 5 June 2020) 


\section{Credits}

This CREID Policy Briefing was written by Dr Joanna Howard (Institute of Development Studies) and co-author (the Indian co-author remains anonymous for security reasons). It was edited by Emilie Wilson and produced as part of the Coalition for Religious Equality and Inclusive Development (CREID). CREID is funded by UK Aid from the UK government and provides research evidence and delivers practical programmes to redress the impact of discrimination on the grounds of religion or belief, tackle poverty and exclusion, and promote people's wellbeing and empowerment.

CREID Policy Briefings are published by the Institute of Development Studies (IDS) and aim to share key research findings and make practical recommendations for policymakers and donors.

The opinions expressed are those of the authors and do not necessarily reflect the views or policies of IDS or the UK government.

\section{(cc) BY This is an Open Access publication distributed under the} terms of the Creative Commons Attribution 4.0 International licence (CC BY), which permits unrestricted use, distribution, and reproduction in any medium, provided the original authors and source are credited and any modifications or adaptations are indicated.

DOI: 10.19088/CREID.2021.014

Institute of Development Studies, Brighton BN1 9RE, UK

$T+44(0) 1273606261$

$\mathrm{F}+44(0) 1273621202$

E creid@ids.ac.uk

Wwww.creid.ac

T @CREID_Dev

CREID partners

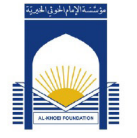

institute of development studies

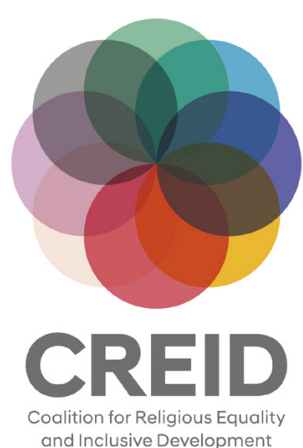

